Pamiętnik Literacki 2015, 2, s. 2-25
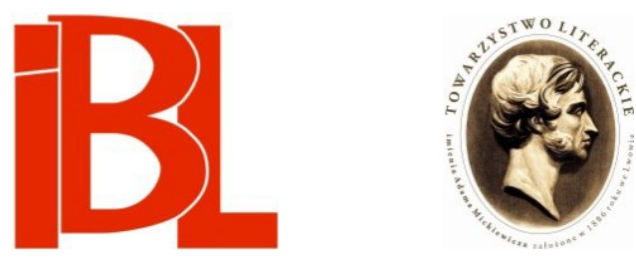

\title{
Józef Ignacy Kraszewski wobec postępu cywilizacyjnego w Europie. Na marginesie relacji z podróży
}

Agnieszka Czajkowska 


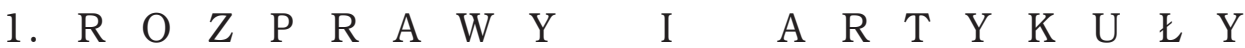

Pamiętnik Literacki CVI, 2015, z. 2, PL ISSN 0031-0514

AGNIESZKA CZAJKOWSKA Akademia im. Jana Długosza, Częstochowa

\section{JÓZEF IGNACY KRASZEWSKI WOBEC POSTĘPU CYWILIZACYJNEGO W EUROPIE NA MARGINESIE RELACJI Z PODRÓŻY*}

Na rozumienie postępu przez autora Kartek $z$ podróży składa się wiele elementów: jego wiedza w zakresie nauk przyrodniczych (był studentem medycyny) i świadomość wynalazków technicznych, poparta profesjonalnymi badaniami $\mathrm{w}$ archiwach znajomość historii i procesów, które nią rządzą, obserwacja przemian gospodarczych, ekonomicznych oraz społecznych w realiach polskich i europejskich, a także doskonałe wykształcenie w dziedzinie historii sztuki i umiejętność określenia rozwoju poszczególnych stylów estetycznych. Wszystkie części składowe pojmowania przemian cywilizacyjnych ulegały ewolucji w toku długiego życia pisarza. Wykazywały jedną cechę wspólną - w przekonaniu Józefa Ignacego Kraszewskiego miały swój rewers etyczny, były o tyle istotne i warte refleksji, o ile mogły służyć lepszemu rozumieniu historii Polski i wizji jej przyszłości. Miały również wymiar partykularny - kształtowały tożsamość autora Starej baśni, przekładały się na jego sposób życia oraz twórczość artystyczną i działalność społeczną. Szkic niniejszy podejmuje tylko częściową prezentację zagadnienia, przeprowadzoną na materiale relacji Kraszewskiego z podróży i dotyczącą jego poglądów na techniczny, cywilizacyjny wymiar postępu.

Idea postępu, choć znana już Sokratesowi i Senece, jest zwykle wiązana z kształtem intelektualnym epoki oświecenia. Stanowiła ona bowiem istotny element atmosfery filozoficznej XVIII w. i już wiek później należała do obiegowych przekonań podzielanych przez ogół ówczesnych Europejczyków. Współtworzyła myśl Immanuela Kanta, stając się podstawą jego nowoczesnej koncepcji filozofii ${ }^{1}$. Określała i dotąd określa pozycję człowieka w świecie i jego egzystencjalne oczekiwania, będąc wyrazem przekonania o linearnej naturze dziejów i o kierunku, w którym zmierza historia. Swoją definicję idea postępu zawdzięczała Anne-Robertowi-Jacques'owi Turgotowi, który w 1750 r. sformułował koncepcję rozwoju cywilizacyjnego, podległą prawu „czterech postępów”: nauki, techniki, obyczajów i twórczości artystycznej2 Nierównomierne tempo postępu osiagane przez każdy z czterech wymienionych

* Za inspirację dziękuję pani prof. Lucynie Rożek.

1 Zob. Z. Kra s n o dę b s ki, Upadek idei postępu. Warszawa 1991, s. 47: „Kant był jednym z tych myślicieli, którzy ukuli pojęcie postępu. Choć [...] nie do końca podzielał optymizm oświecenia, [...] mimo wszystko wierzył w jej [tj. ludzkości] postęp cywilizacyjny i moralny".

2 Pisze o tym B. B a cz k o w pracy Rousseau: samotność i wspólnota (Warszawa 1964, s. 203 n.).

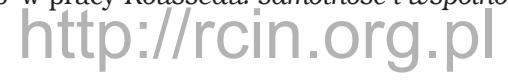


elementów stanowiło o miejscu, w którym znajduje się dana społeczność na ogólnej mapie rozwoju ludzkości, tłumaczyło odmienność kulturalną i cywilizacyjna poszczególnych narodów. Przez oświeconych, przyjmujących swoją racjonalność za miernik wartości epok poprzednich oraz przekonanych, że ludzkość zmierza w kierunku udoskonalania społecznych instytucji i urządzeń, postęp był określany w kategoriach naturalnego i powszechnego prawa, które rządzi rozwojem. Sądzono, że jest on koniecznością, nie możliwością. Antoine Nicolas Condorcet w swojej pracy Szkic obrazu postępu ducha ludzkiego poprzez dzieje formułował idealistyczną koncepcję rozwoju społecznego, wynikającą z optymistycznego przeświadczenia, że, jak pisze:

nie zakreślono żadnej granicy rozwojowi ludzkich uzdolnień, [...] człowiek posiada nieograniczone możliwości doskonalenia się, [...] jego postęp niezależny jest od wszelkich potęg, które chciałyby go zahamować, [...] jedynym jego kresem jest kres trwania globu, na który rzuciła nas natura ${ }^{3}$.

W myśl tego stwierdzenia Condorcet podzielił dzieje ludzkości na epoki, których granicami stały się poszczególne wynalazki techniczne. Okres sobie współczesny postrzegał w perspektywie intensywnego rozwoju nauk przyrodniczych, które miały się stać podstawą dobrobytu człowieka. Filozof naiwnie wierzył, że poczucie bezpieczeństwa materialnego spowoduje przyrost ludności i jej udoskonalenie moralne. Ironicznym przypisem do głoszonych przez niego poglądów stało się samo życie - Condorcet ginie w trakcie historycznej realizacji idei postępu - podczas Wielkiej Rewolucji Francuskiej. Swoje dzieło kończy słowami, które wyraźnie nawiązuja do sytuacji osaczenia intelektualisty przez podległy prawom historii tłum i stają się metafora jego śmierci:

Obraz rodzaju ludzkiego wyzwolonego $\mathrm{z}$ wszelkich pęt, oswobodzonego $\mathrm{z}$ władzy przypadku i wrogów postępu, zdecydowanie zmierzającego ku prawdzie, cnocie i szczęściu, jakżeż jest wielką pociechą dla filozofa wobec ogromu błędów, zbrodni i niesprawiedliwości, które wciąż jeszcze kalają ziemię i których ofiarą niejednokrotnie sam pada! Kontemplując ten obraz przekonuje się o wartości swych trudów $\mathrm{w}$ walce o postęp rozumu w obronie wolności [... $]^{4}$.

Chociaż idea postępu należała do fundamentów oświecenia, nie miała, jak pisze Bronisław Baczko w swojej pracy poświęconej Jeanowi-Jacques'owi Rousseau, jednoznacznej wykładni i była różnie definiowana przez XVIII-wiecznych filozofów ${ }^{5}$. Powszechnie podzielane przekonanie o sukcesywnym rozwoju ludzkości pozwoliło definiować prawa historii, nie pozostawało także bez znaczenia dla teorii stosunków społecznych. Już wtedy wszakże idea postępu podlegała krytyce, którą najpełniej ucieleśniała ustanawiająca jednostkowy punkt widzenia i nakierowana przeciw kulturze jako wytworowi społeczeństwa myśl filozofa z Genewy. W Rozprawie o pochodzeniu i podstawach nierówności między ludźmi Rousseau ujmował sztandarową ideę oświecenia i podwaliny jego optymizmu filozoficznego - nieustanny progres - jako deformację, zepsucie i deprawację człowieka. Jean Starobinski pisał o Roz-

3 A. N. C o n d o r c et, Szkic obrazu postępu ducha ludzkiego poprzez dzieje. Wstęp B. S u c h o d olski. Przekł. E. Hartleb, J. Strzelecki. Warszawa 1957, s. 5.

Ibidem, s. 246-247.

B a c zko, op. cit., s. 203 n.

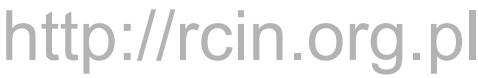


prawie, że jest ona: „historią cywilizacji jako postępującej negacji naturalnej podstawy, jako postępu, który oznacza degradację pierwotnej niewinności. Historia techniki jest przedstawiona w ścisłym związku z moralna historia ludzkości”b.

Swój program odwrotu od cywilizacji Rousseau formułował także w Emilu, który - obok specyficznej teorii wychowania - zawierał uwagi na temat historii, sposobów jej przedstawiania i wartości edukacyjnej narracji dziejowych. W efekcie Rousseau zbudował obraz świata podzielonego na treść i formę - istotę i fałszywy pozór, który utożsamiony został z wytworami kultury i który uniemożliwiał bezpośrednie doznania oraz autentyczność w relacjach między ludźmi. Pisał o konstruowaniu dziejów, antycypując XIX-wieczne wypowiedzi teoretyczne (np. Kraszewskiego) i praktykę romantycznej powieści historycznej:

Dodajmy do wszystkich tych uwag, że historia ukazuje raczej czyny niż ludzi, ponieważ chwyta ich jedynie w chwilach wybranych, w strojach na pokaz, wystawia ona tylko człowieka, przygotowanego na to, by być widzianym; nie towarzyszy mu w domu, w gabinecie, na łonie rodziny, pośród przyjaciół, maluje go w chwili reprezentacji, odtwarzając raczej strój jego urzędowy niż osobę ${ }^{7}$.

Jak wynika z przytoczonej wypowiedzi, historia pojmowana jako reprezentacja dziejów wcale nie zawiera w sobie postulatu pełni, całości, wyczerpywalności. Wręcz przeciwnie - dopuszcza do głosu jedynie część materii życia, właśnie pod postacia tego, co dla linearnego rozwoju reprezentatywne. Dokonujące się w ten sposób zafałszowanie obrazu dziejów stało się przedmiotem krytyki XVIII-wiecznego intelektualisty i określiło zasady XX-wiecznych działań dekonstruujących tradycyjne narracje historyczne.

Wyczulenie Rousseau na pozór i formę zewnętrzną, którą utożsamiał z rozwojem cywilizacji, spowodowało jego intelektualną negację historii pojmowanej w kategoriach postępu, ale także - w przestrzeni własnej biografii - odwrót od królewskiego dworu i związanej z nim europejskiej kariery. Ponawiane przez filozofa ucieczki - z Genewy, z Paryża, świadome przybieranie przez niego postawy permanentnego wygnańca, oznaczało też dystans wobec społecznych kosztów rozwoju, nierównomiernie rozkładanych na poszczególne klasy. Zerwanie $z$ oficjalnością stanowiło w tamtym czasie dobrowolne wykluczenie ze świata „oświeconego”, którego wzór był tworzony przez filozofów zgodnie $z$ regułami ratio. Przejście na stronę „nierozumu”, jak to nazwał Michel Foucault w swojej Historii szaleństwa $w$ dobie klasycyzmu, oznaczało przede wszystkim odrzucenie racjonalnego dyskursu, pojmowanego jako zespół przekonań epistemologicznych właściwych dla określonej formy kultury, i pozwoliło przyjrzeć się „podszewce” postępu, wyrazić to, co pozostało „nieoświecone”. Ucieczka Rousseau umożliwiła także symboliczne ujawnienie podstawowego rozdźwięku między postulowanym przez myślicieli kształtem rzeczywistości a jej doświadczeniem oraz, co za tym idzie, na ujęcie idei postępu w kategoriach etycznych.

Badajacy klasycystyczny dyskurs „rozumu” Foucault wskazywał na jego opre-

6 J. Starobinski, Jean-Jacques Rousseau: Przejrzystość i przeszkoda, oraz Siedem esejów o Rousseau. Przeł. J. W oj ci e s za k. Warszawa 2000, s. 35.

7 J. J. Rou s s ea u, Emil, czyli $O$ wychowaniu. Do druku przygot. F. Wn or ow ski. Wstęp, komentarz J. Le gowicz. T. 2. Przeł. E. Zieliński. Wrocław 1955, s. 49. 
syjny charakter, realizujący się poprzez marginalizowanie tych członków społeczeństwa, którzy - z wyboru czy z konieczności - kwestionowali racjonalne założenia umowy i podlegali władzy różnie pojmowanego szaleństwa. Oświecenie, by uzyskać dyktat nad dyskursywną reprezentacją rzeczywistości, posługiwało się środkiem zaradczym w postaci internowania, które, jak pisze autor Historii szaleństwa $w$ dobie klasycyzmu:

miało niweczyć bezrobocie lub przynajmniej zacierać jego najjaskrawsze skutki, a poza tym - służyć za instrument kontroli płac, gdy groziła ich zwyżka. Oddziaływać kolejno na rynek pracy i koszty produkcji. [...] chodziło przede wszystkim o zamaskowanie nędzy i zapobieżenie politycznym i społecznym kłopotom, jakie mogła powodować $[\ldots]^{8}$.

Powstające wówczas miejsca odosobnienia miały, jak pisze Foucault, dwojakie konsekwencje: ekonomiczne i etyczne. $Z$ jednej strony, pozwalały sterować gospodarką pieniężna, $z$ drugiej - ułatwiały zapomnienie o tym, co pozasystemowe, oraz zwalniały z poczucia odpowiedzialności za nieudane eksperymenty na społeczeństwie.

Dopiero w drugiej połowie XIX w. koszty racjonalnego postępu stały się przedmiotem refleksji i przeniknęły do powszechnej świadomości, czego przykładem jest praca amerykańskiego ekonomisty, Henry'ego George'a, Postęp i nędza. Została ona przetłumaczona na język polski i wydana w Poznaniu w 1885 roku. O ile, jak wiadomo np. z książki Charlesa Van Dorena9 ${ }^{9}$, wiek XVIII cechował gwałtowny rozwój wiedzy, poprzedzony dokonaniami Kartezjusza, Leibniza i Keplera, mierzony osiagnięciami Newtona, postępami w algebrze, astronomii, fizyce i chemii ${ }^{10}$, o tyle wiek XIX to czas wykorzystania nowych odkryć dla spotęgowania rozwoju gospodarczego. Pisze George:

Cechą naszego stulecia jest nadzwyczajny wzrost siły wytwarzającej bogactwo. Zastosowanie pary, elektryczności, wprowadzenie ulepszonych sposobów produkcji i mechanizmów zmniejszających pracę ludzką, większy podział pracy w produkcji i szersza jej skala, niezmierna łatwość wymiany, wszystko to spotęgowało wydajność pracy ${ }^{11}$.

Spostrzeżeniom ekonomicznym zawartym w cytowanej rozprawie towarzyszyły wnioski na temat społecznych konsekwencji przemian gospodarczych, spośród których dla autora najważniejszy był wzrost nędzy i nasilenie się walki o byt.

M. F o u c a u lt, Historia szaleństwa w dobie klasycyzmu. Przeł. H. Kę s zy c ka. Wstęp M. C z e rwińs ki. Warszawa 1987, s. 74.

Ch. Van Dor en, Historia wiedzy od zarania dziejów do dziś. Przeł. B. Stokłos a, R. Goł ę d ow s ki. Warszawa 1996, s. 280 n.

10 O postępie w dziedzinie nauk przyrodniczych pisze C o n d o r c e t (op. cit., s. 186): „Poznano i zmierzono ciężar powietrza, odkryto, że światło nie rozchodzi się momentalnie, i obliczono jego prędkość; obliczono, jaki wywiera to wpływ na pozorne położenie ciał niebieskich; promień słoneczny rozłożono na promienie prostsze [...]. Wyjaśniono zjawisko tęczy i poddano obliczeniom środki wiodące do wytwarzania jej barw i ponownego ich złożenia. Elektryczność [...] staje się jednym z powszechnych zjawisk wszechświata. Przyczyna piorunu przestaje być tajemnica [...]. Nowa nauka, meteorologia uczy poznawać, a niejednokrotnie przewidywać zjawiska atmosferyczne [...]".

11 H. Ge orge, Postęp i nędza. Badanie przyczyn sprowadzajacych przesilenia przemysłowe oraz wzrostu nędzy jednocześnie z wzrostem bogactwa. Przeł. M. D. Poznań 1885, s. 3.

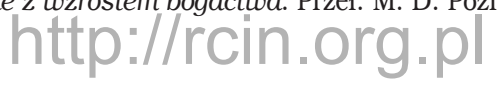


Polemiczną wobec racjonalnej wizję postępu tworzono w XIX w. ze stanowiska religijnego. W roku 1840 w Paryżu Józef Ordęga wydaje książkę, w której znaczenie postępu sytuuje na fundamencie wiary ${ }^{12}$. Wyraża tam przekonanie, że instytucja sprawczą wszelkiego ruchu jest Bóg, decydujacy o sile i kierunku rozwoju ludzkości $^{13}$. Poglądy XIX-wiecznego działacza politycznego i czytelnika Philippe’a-Josepha-Benjamina Bucheza - autora dzieła Essai d'un traité complet de philosophie du point de vue du catholicisme et du progrès - były w sposób oczywisty związane $z$ religijnym rozumieniem postępu. Francuski filozof wyprowadził je $z$ Biblii, w jego interpretacji progres utożsamiony został $\mathrm{z}$ moralnym doskonaleniem człowieka i drogą do zbawienia. Chrześcijańskie pojmowanie postępu zakładało również działania na rzecz wspólnoty i jej dobra. Takie poglądy cechowały także Kraszewskiego, przejawiały się w jego krytyce warstwy ziemiaństwa ze stanowiska solidaryzmu społecznego oraz w próbach konstruowania - dla Polski i świata - mesjanistycznego scenariusza, który w polskich warunkach wyrastał $z$ odziedziczonej po oświeconych rozpaczy z powodu utraty ojczyzny. Koncepcja intelektualnego opanowania historii i wiara w sensowność cierpienia narodu rozwijały się w XIX w. szczególnie w Wielkopolsce i na emigracji, chłonąc millenarystyczno-mesjanistyczne idee myśli francuskiej. Badając związki filozofii Augusta Cieszkowskiego, Bronisława Trentowskiego, Karola Libelta oraz paryskich prelekcji Adama Mickiewicza z koncepcjami francuskich myślicieli (Ballanche’a, de Maistre’a i innych), Andrzej Walicki pisze:

Nie będzie [...] przesadą twierdzenie, że niemal wszystkie główne idee polskiego mesjanizmu inspirowane były przez myśl francuską lub przynajmniej znajdowały w niej mniej lub więcej dokładne odpowiedniki ${ }^{14}$.

Wśród owych idei wymienia autor pracy Filozofia a mesjanizm pojęcie postępu, które rozumiano w XIX w. w kategoriach ekspiacyjnych - kolejne dramatyczne próby dziejowe (rewolucja) miały być elementem kolektywnej rehabilitacji człowieka i droga do osiagnnięcia zbawienia ludzkości.

Klimat intelektualny romantyzmu, jaki kształtował Kraszewskiego, został przygotowany - prócz wymienionych wcześniej fundamentalnych dla naszej literatury uwarunkowań - przez Wielką Rewolucję Francuską. Nie bez znaczenia dla powszechnego odczucia oraz wynikającego stąd pojmowania postępu była także pamięć o trzęsieniu ziemi w Lizbonie, które miało miejsce w 1755 roku ${ }^{15}$. Odcisnęło ono poważne piętno na oświeceniowym optymizmie. Katastrofa zachwiała wiarę w racjonalny porządek wydarzeń na ziemi. W wypowiedziach ówczesnych filozofów, m.in. Woltera, pojawiły się pytania o istnienie zła na ziemi i o jego naturę. Ten szkic atmosfery, w jakiej wyrastał Kraszewski, można wzbogacić o cechy wykształcenia polskiego. Warszawa 1970, s. 22-23.

Piszę o tym w artykule Powszednie i powszechne. Katastrofy Kraszewskiego (na przykładzie podróży) (w zb.: Kulturowe paradygmaty końca. Studia komparatystyczne. Red. J. C. Kałużny, A. Żywiołek. Częstochowa 2013).

J. Or d ęga, O narodowości polskiej z punktu widzenia katolicyzmu i postępu. Paryż 1840. Ibidem, s. 4.

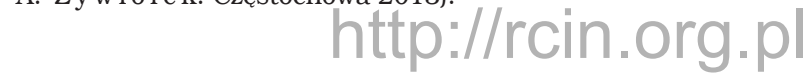


pisarza. Zdobywał je w tych samych murach co filomaci - późniejsi uczeni: geografowie, przyrodnicy, a także podróżnicy czy znakomici językoznawcy (dość wymienić Józefa Kowalewskiego, znanego mongolistę). Klimat Uniwersytetu Wileńskiego w pierwszej połowie w. XIX, w którym wykładali znani w Europie ze swych publikacji uczeni tej miary co Jan (matematyk) i Jędrzej (chemik i lekarz, twórca biochemii) Śniadeccy, dawał solidny fundament pod badania naukowe i tworzenie filozoficznych teorii zwiazków człowieka $z$ wszechświatem. Jeszcze zanim urodził się autor Ulany, znana była w Wilnie praca Jędrzeja Śniadeckiego Teoria jestestw organicznych. W latach 1810 i 1821 tłumaczono ją na język niemiecki, a w 1835 r. na francuski, co pozwala sądzić, że miała znaczenie nie tylko dla rodzimego obiegu wiedzy. Był to systematyczny wykład na temat organizmów żywych i ich powiązań. Prezentowana przez Śniadeckiego teoria życia ujmowała je ,jako ciagła ogólna przemianę materii” ${ }^{16}$. Pracę można traktować jako antycypację dialogu, który toczył się we Francji (pod wpływem katastroficznych poglądów Georges'a Cuviera) i obejmował problemy łączące się $z$ pochodzeniem życia na Ziemi oraz naturalnego powiązania poszczególnych form istnienia.

Uczelnia wileńska pozostawała pod wpływem przypadającego na pierwszą połowę XIX w. rozwoju matematyki oraz jej - „królowej nauk” - roli w poznaniu wszechświata (rozwój mechaniki nieba, powstanie astrofizyki). U progu stulecia odkryto pierwsza planetoidę: Ceres. W roku 1846 zauważono planetę Neptun. Stało się to możliwe dzięki wzrostowi precyzji pomiarów astronomicznych. Należy w tym miejscu dodać, że tą dziedziną wiedzy zajmował się z sukcesem brat pisarza, Kajetan. Temat obserwacji nieba przy zastosowaniu rozmaitych przyrządów pojawiał się często w korespondencji braci z lat pięćdziesiątych i późniejszej ${ }^{17}$.

Na Uniwersytecie Wileńskim w 1804 r. powstała pierwsza na ziemiach polskich katedra mineralogii, uznawanej przez oświeconych i ich romantycznych potomków za jeden z najważniejszych działów nauk o ziemi. Trzeba zaznaczyć, że w wileńskim gabinecie mineralogicznym było 20000 eksponatów (pochodziły one z kolekcji Joachima Chreptowicza, Romana Symonowicza i Karola F. Eichwalda). Wcześniej taki gabinet został stworzony przez Tadeusza Czackiego w Krzemieńcu i składał się z 15000 eksponatów. Zbiory zgromadzone w Atenach Wołyńskich ściśle wiązały się z dydaktyką uniwersytecka, a odbywane w liceum zajęcia - jak piszą autorzy Historii nauki polskiej - stanowiły istotny czynnik kształtowania się terminologii i pojęć mineralogicznych ${ }^{18}$. Z tego środowiska wyrasta znakomity geolog - Ignacy Domeyko. Kiedy w 1829 r. Kraszewski rozpoczyna na Uniwersytecie studia medyczne, ma okazję zetknąc się z kilkoma wileńskimi wydaniami aż trzech różnych podręczników z zakresu mineralogii.

Jak wspomniano wcześniej, w pierwszej połowie XIX w. Wilno było również

Historia nauki polskiej. Red. B. Su chodolski. T. 3: 1795-1862. Red. tomu J. Michalski. Wrocław 1977, s. 489.

17 J. I. Kr a s z e w s ki, list z Żytomierza, z 28 III 1855. W: Listy do rodziny 1820-1863. Cz. 1: W kraju. Oprac. W. Dan ek. Wstęp S. Burkot. Kraków 1982, s. 294-295. Pisarz kolekcjonował z myślą o bracie minerały występujące na Wołyniu - o możliwości kupna gotowej kolekcji donosi w liście z 29 X 1855 (w: jw., s. 311-312, 319). 
ważnym ośrodkiem badań astronomicznych, prowadzonych przez Jędrzeja Śniadeckiego (uniwersytet posiadał obserwatorium). Nie bez znaczenia pozostawały także badania meteorologiczne.

Inicjatorami i organizatorami sieci meteorologicznej na terenie Wileńskiego Okręgu Naukowego, bardzo rozbudowanej, bo liczącej w latach 1803-1831 ok. 60 stacji obserwacyjnych, działających głównie przy szkołach, byli Józef Mickiewicz i Tadeusz Czacki ${ }^{19}$.

Józef Mickiewicz był autorem pionierskiej instrukcji do obserwacji meteorologicznych oraz traktatu $O$ meteorologii i sposobie obserwacji meteorologicznej.

Jak wynika z poczynionych uwag, klimat miasta i uniwersytetu, w którym studiował przyszły pisarz, nie mógł nie wpłynąc na jego formację umysłową. Począwszy od 1834 r. Kraszewski, wyposażony w solidną wiedzę na temat kształtu świata i zjawisk nim rządzących, zdobywający sławę literacką (był 4 lata po debiucie), do tego wychowany w tradycyjnej atmosferze syn obywatela ziemskiego, osiadłego we wsi Dołhe, odpowiadając na postulaty romantycznego poznawania „swojszczyzny”, rozpoczyna wędrówki krajoznawcze, które najpierw odbywać się będą na ziemiach polskich, później, w latach pięćdziesiątych i sześćdziesiątych, obejmą swym zasięgiem kraje Europy Zachodniej. Podróże te były, jak w przypadku oświeceniowych poprzedników, okazją do dokumentowania pozostałości po niepodległej Rzeczpospolitej. Umożliwiały również pisarzowi konfrontację ze współczesną mu kulturą oraz życiem codziennym mieszkańców odwiedzanych wsi i miasteczek. Relacje z owych podróży są do dzisiaj, jak zauważa Rostysław Radyszewski, ważnym świadectwem przeszłości Ukrainy z punktu widzenia historyka i etnografa ${ }^{20}$. Obserwacje Kraszewskiego dotyczyły bowiem - obok szczegółów geograficznych, miejscowych legend, pieśni, ubiorów - także sposobu gospodarowania i stosunków panujących między wsią, dworem i Żydami. Autor Ulany, mimo że wychowany w poszanowaniu przeszłości, zdawał sobie sprawę z nieuchronności zmian, wśród których za najważniejszą dla swojego środowiska uznawał uwłaszczenie chłopów. Krytyka pańszczyzny, która stała się efektem spostrzeżeń pisarza, wymierzona była przeciwko beneficjentom systemu wykorzystującego pracę najbiedniejszych mieszkańców wsi. Deklarowana przez ziemian przynależność do nowoczesności, mimo konserwowania anachronicznych sposobów produkcji, w obserwacji i ocenie podróżnika okazywała się pozorem. Pisze Kraszewski w swojej relacji z podróży po ziemiach polskich o wołyńskich „postępowcach”:

kto czyta po francusku, gra w wista, lubi literaturę i myśli, że na tym dosyć, aby zyskać imię ucywilizowanego człowieka, człowieka dobrze wychowanego, dobrego tonu i towarzystwa, ten nie rozumie, co to jest cywilizacja, co to jest ten progres, który ciagle mając na ustach, sądzi, że on przyjdzie sam bez żadnych ofiar ${ }^{21}$.

Format postępu obserwowanego w miniaturze na przykładzie Wołynia, Polesia

Ibidem, s. 578.

R. Ra dy s z e w s kyj, Podorożi ta memuarystyka. W: Juzef Ihnacij Kraszewskyj: diałoh iz Ukrajinoju. Kyjiw 2012, s. 28.

J. I. Kr a s ze w s ki, Wspomnienia Wotynia, Polesia i Litwy. Przygot. do druku, wstęp S. B u rk ot. Wyd. 2. Warszawa 1985, s. 142. 
i Litwy miał swój odpowiednik w refleksji Kraszewskiego także w skali kontynentalnej i globalnej. Nie darmo autor Ulany był człowiekiem XIX stulecia, który miał świadomość uczestnictwa w historii oraz orientował się w próbach intelektualnego jej wykorzystania, które, jak pisze Budrewicz, było dla niego „probierzem dojrzałości cywilizacyjnej oraz gwarantem kontroli rozwoju świata pod względem moralnym, postęp bowiem ma sens wtedy, gdy pomnażając dobra materialne, jednocześnie dba o człowieka"22.

Jako początkujący podróżnik miał Kraszewski ogólne wyobrażenie na temat rozwoju cywilizacyjnego, miał również świadomość zdobyczy techniki na zachodzie Europy, zwłaszcza zaś produkcji maszyn i urządzeń, pomocnych w wytwarzaniu sukna, papieru czy cukru. Słusznie wiazał to $z$ upowszechnianiem wiedzy, na stronicach swoich wspomnień z podróży domagał się utworzenia na Wołyniu „szkoły politechnicznej"23, która sprzyjałaby rozwojowi przemysłu. Zarazem na marginesie konstatował niechęć Polaków do nauki, do korzystania $z$ doświadczeń innych narodów i brak zainteresowania rodaków nowoczesnymi teoriami gospodarowania. Obserwacja rodzimego środowiska pozwalała także na ocenę rozwijającego się na ziemiach polskich handlu i gospodarki pieniężnej. Kraszewski miał pewne doświadczenie w dziedzinie finansowej - jako gospodarz ziemski był aktywnym uczestnikiem kontraktów w Dubnie, które sportretował w Latarni czarnoksięskiej, również Wspomnienia Wotynia, Polesia i Litwy zawieraja wzmiankę o tym corocznym wydarzeniu handlowym i kulturalnym. Obserwowane na Wołyniu nieśmiałe początki kapitalizmu stają się przedmiotem krytyki pisarza, który zauważał, że bogacenie się ma związek z zanikiem solidarności społecznej i takich cech charakterystycznych dla kultury szlacheckiej, jak otwartość i gościnność. W pisanych później w kraju i na emigracji powieściach często powraca obraz rozwijającego się na ziemiach polskich handlu. Perspektywa, z której jest on ujmowany, łączy się, jak pisze Ewa Ihnatowicz, z kategoriami moralnymi i sytuacją narodu bez państwa: „Jak wiadomo, jest to etyka doskonalenia i samodoskonalenia, etyka polskiej autoświadomości, etyka polskiego domu-enklawy, [...] etyka solidaryzmu [...]"24. W tworzonej już na emigracji, w latach osiemdziesiąych, powieści Kopciuszek Kraszewski portretuje XIX-wieczną Warszawę jako miejsce narodzin nowoczesnego sposobu sprzedaży i kupna. Krytyka postępu w tej dziedzinie dotyczy mechanizmów, które dziś, w XXI stuleciu, sa powszechnie stosowane przez firmy oferujące swoje produkty. Pisze Kraszewski u schyłku w. XIX:

Nagle zaczęto rachować w handlu i rzemiośle nie na te uczucia serca ludzkiego zacne i poczciwe, ale wypotrzebowywać słabości... Obrachowano, co może próżność, ciekawość, łatwowierność i na tym budować się poczęto, śmiejąc się z tych, którzy się łapać dawali w przekonaniu, że zawsze się ich dość znajdzie i na jutro. Gdy wprzódy podstawą stosunków między pracą a nabywcą była wiara i poszanowanie, gorączka wieku, której siły w przyszłości nie zaprzeczam bynajmniej, znalazła, że te dwa bodźce za mało były czynne, wyszukała innych i w ręce szarlatanerii rzuciła rzemiosło i handel. Od tego to warszawskiej (okres drezdeński). W zb.: Europejskość i rodzimość. Horyzonty twórczości Józefa Ignacego Kraszewskiego. Red. W. Rataj cza k, T. S o bi er a j. Poznań 2006, s. 41.

24 E. I h n a tow i z z, Złote jabłko, złoty Jasieńko. Pieniadz i bogactwo $w$ powieściach wspótczesnych Kraszewskiego: problematyka etyki dziewiętnastowiecznej. W zb.: Europejskość i rodzimość, s. 214.

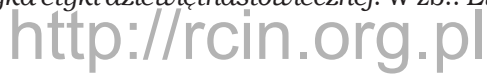


czasu warsztat szewiecki stał sie magazynem obuwia; krawiec - artystą kroju; stolarz - zatytułował sklep składem mebli. Znikły skromne szyldy, które oznajmywały rzecz, a nie nęciły oczów, i powstały błyszczące i brzmiące napisy, złocenia, obietnice, przemawiające do oczów i kieszeni pokusy ${ }^{25}$.

Krytyka postępu, obserwowanego na przykładzie zmieniających się obyczajów w handlu, wynika $z$ konfrontacji kategorii etycznych $z$ działaniem na rzecz maksymalizacji zysku. W dzisiejszym czytelniku spostrzeżenia pisarza nie budzą zdziwienia - jesteśmy wszak poddawani agresywnemu działaniu reklamy, zwłaszcza obliczonej na percepcję podprogową. Kraszewski - jako narrator Kopciuszka-chciałby, aby sprzedaż towarów służyła zaspokajaniu potrzeb, nie próżności ludzkiej, a w miejscu chwytliwej reklamy znajdowała się uczciwa informacja o oferowanych przez sklep przedmiotach. Chciałby również, aby handlem zajmowali się ludzie wyposażeni w podstawowe wartości moralne, aby byli integralną częścią społeczeństwa, a nie, jak dotychczas, osobna, zamkniętą i powszechnie pogardzana grupa. Powstała u schyłku życia przebywającego na emigracji pisarza powieść wyraża z pewnością odczucie ogólnego kryzysu, które Arnold Hauser obserwuje w latach siedemdziesiatych w. XIX w związku $\mathrm{z}$ wydarzeniami Komuny Paryskiej. Miały one swoje konsekwencje nie tylko dla ukonstytuowania się międzynarodowego ruchu robotniczego i kolejnych, już XX-wiecznych rozruchów, ale także dla kształtu kapitalizmu finansowego i przemysłowego. Mimo że rewolucja francuskich robotników zakończyła się klęską, pozostało po niej, jak pisze Hauser, powszechne poczucie niepewności, które nie mogło być stłumione przez gwałtowny rozwój techniki i ciagłe ulepszanie metod produkcji. Wręcz przeciwnie - „rozbudzenie nieraz bezsensownej i bezowocnej żądzy czegoś nowego, bezustanne dążenie do nowości wyłącznie dla niej samej" 26 jest w Społecznej historii sztuki i literatury dowodem doświadczania pustki duchowej i gwałtownych przewartościowań w świecie idei. Mieszkający w tym czasie w Dreźnie pisarz (przeżywający zresztą burzliwe wydarzenia we własnym życiu), portretując środowisko kupieckie i nowe metody oddziaływania reklamy, dawał w ten sposób wyraz swojemu niepokojowi z powodu kierunku, w jakim rozwijała się europejska cywilizacja.

W roku 1859 autor Ulany publikuje na łamach „Dziennika Literackiego” cykl wypowiedzi, które złożą się na książkę zatytułowaną Wieczory wołyńskie. Wyrażone $\mathrm{w}$ niej oraz $\mathrm{w}$ prasie poglądy stały się przedmiotem gwałtownego zatargu Kraszewskiego z miejscowym ziemiaństwem na tle „sprawy włościańskiej”27 i w konsekwencji doprowadziły do wyjazdu pisarza do Warszawy. Oceny i tezy Z „Dziennika Literackiego” i z książki o tyle mogą być istotne w tym miejscu, że kompozycja całości stanowi - jak zauważa Iwona Węgrzyn - interesującą mieszaninę gatunkową, zawierającą w swojej strukturze m.in. „szkic krajoznawczy, który wyrastając $z$ tradycji literackich wędrówek [...], rozważania na temat historii krainy, poszczególnych miejscowości, ich architektury łączy z refleksją społeczną rzyński. Cz. 2. Warszawa 1974, s. 315.

Na ten temat pisze szczegółowo I. W ęg r zy n w artykule Dylematy tradycjonalisty - watpliwości reformatora - samotność twórcy. „Wieczory wotyńskie” Józefa Ignacego Kraszewskiego (,Wiek XIX. Rocznik Towarzystwa Literackiego imienia Adama Mickiewicza” 2012). 
i moralną"28. Wieczory wołyńskie sa próbą określenia się Kraszewskiego wobec obserwowanych zmian w sposobie gospodarowania oraz w strukturze społecznej mieszkańców dawnych ziem polskich. Książkę cechuje obywatelska troska o los prowincji oraz przekonanie o nieuchronności postępu technicznego i w ślad za nim - obyczajowego. Jest ono konfrontowane $z$ utrwalonym kanonem wartości, oprócz dekalogu promującym poszanowanie tradycji szlacheckiej i nadrzędną świadomość przynależności do narodu polskiego. Utwór rozpoczyna deklaracja ideowa pisarza:

Nie jestem ja wcale przyjacielem reform nierozważnych, które dając grosz pozbawiają nas charakteru i zrywają stosunek nasz dziejowy z przeszłością, ale pojmuję dobrze, że w duchu swoim własnym i w stosunku możności powinnibyśmy myśleć o sobie i brać się do czegoś. Nie święćmy nic ulepszeniom i zostańmy ubodzy bodaj ze sobą, ale gdzie mamy możność sobie i drugim byt osłodzić, nic nie tracąc, czemuż nie pracować? Nie poświęciłbym najmniejszej pamiątki największym korzyściom materialnym dla kraju, ale czyż nie ma innej dla postępu drogi, jak przez cmentarz i kościoły? Nie uważam za najpierwszy obowiązek bogacić się, ale nie sądzę, by uczciwie zdobyta zamożność grzechem być miała, byle do niej serce nie przylgnęło, byle jej godności i charakteru nie poświęcić.

Zresztą nie o postęp gospodarski domagam się, nie o fabryki, nie o drogi, ale o oświatę dla ludu, ale o chleb dla kapłanów, ale o wsparcie dla języka, o poszanowanie przeszłości i niezapieranie się jej czynem.

Co mi po nazwisku, które wnuk wziął po dziadzie, gdy w nim ducha dziadowskiego nie znajduję, gdy tradycja w nim zgasła, gdy się zrzekł spółki i przodkowania i laskę marszałkowską na wazę srebrna przetopił? ${ }^{29}$

W przytoczonym fragmencie wyraźnie widać oryginalne rozumienie postępu przez Kraszewskiego. Rozwój gospodarczy jest dla niego zjawiskiem wtórnym, konsekwencją rozwoju moralnego. Ten $\mathrm{z}$ kolei - jako wynik powszechnej edukacji - ma obejmować wszystkie warstwy społeczeństwa. Droga możliwego postępu wiedzie, jak pisze autor Wieczorów wołyńskich, przez cmentarz i kościoły, czyli poprzez poszanowanie przeszłości i zachowanie prawd wiary. Rozwój cywilizacji Kraszewski wiąże $z$ doskonaleniem się etycznym tak pojedynczych ludzi, jak i całego, pojmowanego w kategoriach organicznej jedności, narodu. Wieczory wołyńskie sa przy tym przykładem recepcji filozofii mesjańskiej, która uczy, jak doświadczane cierpienia przekuwać na wiarę w przyszłość. Jest bowiem w utworze otwarta perspektywa możliwej do osiagnięcia niezależności i wielkości. Kraszewski, mimo krytycznego stosunku do współobywateli, widzi szanse na ich duchowe odrodzenie. Pisze:

Co nas różni dziś od społeczności pogańskiej! chyba to, że doskonale wiemy, gdzie prawda, ale dobrowolnie zaniechawszy jej, starym szlakiem grzechu się ciagniemy. Trudno wymagać od ludzi doskonałości, ale żądać mamy prawo dążenia ku niej, starania o nią, widomej walki dla prawdy i cnoty. Społeczność może być zepsuta: jeśli w niej żyje pragnienie postępu i poprawy, nic nie ma straconego, ono ją dźwiga; gdzie obok upadku panuje spokój i zdrętwienie, gdzie, gorzej jeszcze, na poparcie i uniewinnienie błędu wyrabiają się teorie i kują sofizmy, tam nic już nie ma do zrobienia ${ }^{30}$.

Postęp jest przez Kraszewskiego rozumiany nie w kategoriach narzuconego prawa, konieczności, lecz jako wyraz ludzkiego pragnienia. Człowiek staje się w tej

J. I. Kr a s z ew s ki, Wieczory wołyńskie. Lwów 1859, s. 46-47.

Ibidem, s. 122 .

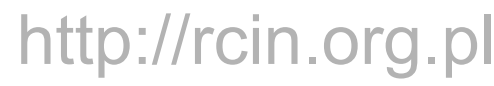


sytuacji nie przedmiotem, ale współtwórcą rozwoju. Pisarz prezentuje chrześcijańskie poglądy na jego możliwości, ważniejsza od błędów popełnianych na drodze cywilizacji wydaje sie przejawiana przez społeczeństwo wola poprawy. Niechęć Kraszewskiego wzbudzają natomiast działania, które redukują znaczenie wyższej instancji, predestynowanej do oceniania i korygowania kierunku rozwoju. Oddanie postępu we władanie tylko ludziom, zgoda na mierzenie przez nich własna miara przemian dokonujących się na świecie i dostosowywanie teorii do praktyki wydaje się pisarzowi zaprzeczeniem możliwości wszelkiego rozwoju i doskonalenia się.

Wieczory wotyńskie projektują oryginalną ścieżkę postępu, wiążąc go $z$ istotą polskiej tożsamości, czyli, jak mniemał autor, z życiem wiejskim. Utwór nie jest jednak apoteozą stylu życia alternatywnego wobec egzystencji w mieście. Kraszewski - krytyk ziemiaństwa wołyńskiego oraz autor wielu powieści ludowych - był na tyle dobrze zorientowany w stosunkach panujących na wsi, że nie idealizował sielskości. Wręcz przeciwnie - malował obrazy bliskie rzeczywistości, nie wahał się mówić na temat obserwowanej nędzy, brudu, zacofania. W swoich książkach zawierał również skarykaturowane portrety współziemian $\mathrm{z}$ ich brakiem wykształcenia, nienaturalnymi ambicjami, brakiem solidarności z biedniejszymi, bezmyślnym wyzyskiem chłopów. Pisał jednak, zwracając uwagę na przewagi rozwoju społecznego opartego na tradycji:

Wioska nie wzbrania nam postępu, nie nakazuje uparcie trzymać się starego, dlatego tylko że stare - bo słusznie powiedział S. Cyprian: Consuetudo sine veritate, vetustas est erroris, ale jej powietrze, jej żywot, jej obyczaj zdrowo i święcie działają na człowieka, nie odrywając go od Boga, trzymając przy wspomnieniach i podaniach, w torze tego żywota, którym żyliśmy wieki. Wieś jest piastunką tradycji i macierzą społeczeństwa naszego ${ }^{31}$.

Cytowany fragment Wieczorów wołyńskich, otwierający cały cykl, ma charakter melancholijnego powrotu do przeszłości, stanowi wspomnienie dawnej jedności i poczucia solidarności między ludźmi. Nie ma tu miejsca na wykluczenie czy obcość społeczna, powszechne przywiązanie do przeszłości tworzy harmonijny obrazek.

Przykładem kraju, gdzie usankcjonowany został rozziew między poszczególnymi klasami społecznymi i gdzie egoizm klas wyższych został uprawomocniony przez instytucje zajmujące się pomocą społeczną, jest dla Kraszewskiego Anglia. Pisze on o tym kraju w swoich Wspomnieniach Wotynia, Polesia i Litwy:

Nie ma przemyślniejszego narodu nad Anglią, ale tam miłosierdzie i litość zostawione są izbom, które fundują azyla, szpitale, domy pracy i ustanawiają taksę dla ubogich, a nędza $z$ wyciagnnioną ręką nie wyciśnie ani pensa nad taksę z kieszeni John Bulla. Zajęcie się spekulacjami, projektami ulepszeń, ekonomią polityczną, chęć wzięcia wszystkiego w kluby normy, w przewidziane ustawami wypadki, oziębiają człowieka, a jeśli się potem zdarzy komu być biednym nie według prawideł, potrzebującym litości prywatnej, pomocy, a bardziej jeszcze pociechy i spółczucia, odsyła go ekonomik do azylów, do domów roboczych, do szpitalów, gdzie prawna litość (charité légale) suchą i zimną ręką zatula rany, lecz je nie goi ${ }^{32}$.

Zagospodarowanie nędzy, znane z relacji o zachodzie Europy i będące spadkiem

32 Kraszews ki, Wspomnienia Wotynia, Polesia i Litwy, s. 233-234.

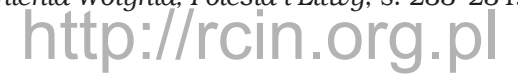


po doświadczeniach oświecenia, nie wydaje się Kraszewskiemu godne naśladowania. Zasiłek zamiast jałmużny, specjalistyczne izby zamiast dobrego serca nie stanowiły o pożądanym przez niego kierunku rozwoju. W warunkach polskich takie pęknięcie wewnątrz społeczeństwa oznaczałoby po prostu niebezpieczeństwo wynarodowienia, któremu pisarz starał się poprzez swoją twórczość i działalność zapobiec. Nowoczesne instytucje niosące pomoc biednym były zbyt „postępowe” w kraju nie posiadającym żadnej choćby namiastki państwa. Podobnie nie jest Kraszewski zwolennikiem znamionującej wzmożoną mobilność społeczną, rozpoczynającej się w Europie unifikacji sposobu życia, ubiorów i obyczajów. Przebywając w 1843 r. w Odessie, zauważa - antycypując globalistyczne cechy społeczeństw w XX w. - tendencje do wyzbywania się narodowych strojów przez Greków mieszkających i handlujących w porcie. Przewaga „suchego i pospolicie brzydkiego"33 stroju europejskiego oznacza dla podróżnika zmierzch różnorodności kulturowej kontynentu oraz zanik przywiązania do tradycyjnych wartości. Także we Włoszech $z$ goryczą konstatuje Kraszewski tendencje do rezygnowania $z$ narodowych strojów:

Typy twarzy stanowiły sprzeczności ponętne dla artysty, ale gdyby je nawet malować zapragnął, cóż by począł z nieszczęsnymi strojami XIX w.? Nawet Turek, wchodząc między cywilizowany naród, przywdział surdut i fez tylko zatrzymał. [K-1 206-207] $]^{34}$

Kosmopolityzm, będacy miarą rozwoju Europy, stanowi w ocenie Kraszewskiego zrzeczenie się $z$ wielokształtności i bogactwa życia. Postęp obserwowany przez pisarza oznacza także industrializację - Odessa ukazywana jest przez niego jako gwałtownie rozrastająca się w przestrzeni i wchłaniająca w swoją strukturę kolejne wioski. Temu zjawisku autor Wspomnień Odessy, Jedysanu i Budżaku właściwie się nie przeciwstawia, rozumie je jako konieczność cywilizacyjną. Dopiero kilka lat później, kiedy będzie miał możność zaobserwowania konsekwencji urbanizacji, zacznie się wypowiadać o miastach-molochach $z$ dużą niechęcią. Postęp stanie się w rozwoju miast synonimem czystości, spokoju, porządku, ale i odrętwienia, braku przejawów życia ${ }^{35}$.

W roku 1858 Kraszewski przedsiębierze podróż do Europy Zachodniej, której trasa obejmuje Włochy, Francję, Belgię i Niemcy. Pisarz w jej trakcie odwiedza takie miasta, jak Kraków (leżący wówczas poza granicami zamieszkiwanego przez niego rosyjskiego dominium), Wiedeń, Wenecja, Padwa, Rzym, Neapol, Marsylia, Tulon, Paryż, Bruksela, Kolonia, Frankfurt, Drezno, Lipsk i Berlin. Dojrzały człowiek, jakim jest już wtedy twórca, ma za sobą liczne doświadczenia podróżnicze po „Swojszczyźnie”. Cechuja go też wyraźnie określone poglądy na temat przemian cywilizacyjnych w Polsce oraz świadomość odmienności życia w Europie Zachodniej. Zamiar odwiedzenia obcych krajów motywuje Kraszewski następująco:

Spędziwszy kilkadziesiąt lat życia na swojej ziemi, myślą zaledwie wybiegając poza jej granice,

J. I. Kr a s z e w s k i, Wspomnienia Odessy, Jedysanu i Budżaku. Dziennik przejażdżki w roku 1843 od 22 czerwca do 11 września. Przypisy, posł. P. He rtz. Warszawa 1985, s. 175.

34 W ten sposób odsyłam do: J. I. Kraszews ki, Kartki z podróży 1858-1864. Przypisy, posł. P. He r tz. T. 1-2. Warszawa 1977. Pierwsza liczba po skrócie, po łączniku, wskazuje tom, następne - stronice. 
przyszło i mnie nareście, z wędrownymi ptakami, które co roku odlatują od nas w cieplejsze kraje, pójść własnymi oglądać oczyma te cuda, których opowiadaniem karmiłem się od dzieciństwa. Wiodła nie tyle rzeczy i spraw ludzkich, wszędzie mniej więcej jednych, ciekawość, ile chęć sprawdzenia tego, co ludzie napisali o cudach obcych krajów. U nas szczególniej nasłuchać się było można do przesytu uwielbień tego, co obce, $z$ pogardą dla tego, co swoje. [K-1 7]

Pisarz formułuje cel podróży przede wszystkim w kategoriach konfrontacji wyobrażeń powstałych na podstawie lektury z zachodnioeuropejską rzeczywistością. Interesuja go zwłaszcza zabytki, pomniki dawnych cywilizacji. Ma świadomość, że pielgrzymuje do źródeł europejskiej kultury, dlatego też ważnymi elementami jego wędrówki są odwiedziny muzeów, drobiazgowo w Kartkach $z$ podróży zrelacjonowane. Lecz jednym z pierwszych podróżniczych doświadczeń okazało się spotkanie z rygorami towarzyszącymi przemieszczaniu się i przekraczaniu granic. Cywilizacja zachodnioeuropejska okazuje się uporządkowana w sposób, który zagraża dotychczasowym przyzwyczajeniom podróżnika. Kraszewski z humorem opisuje nowoczesny środek transportu, jakim jest napędzany parą pociag, i sytuację uprzedmiotowienia, w jakiej znajduje się podróżny. Prowincjusz udający się do wielkiego świata protestuje przeciw postępowi, który zniewala człowieka i odbiera mu poczucie godności. Sprzeciwia się również sposobowi poznawania, który eliminuje z podróży wrażenia niezaplanowane, nieujęte w rozkładzie zwiedzania. Taki model realizowany jest właśnie dzięki możliwości szybkiego przemieszczania się z miejsca na miejsce za pośrednictwem kolei. Swoje wrażenia $z$ górskiej drogi z Wiednia do Triestu Kraszewski tak referuje:

W tych warunkach szybkości nikt dotąd z ludzi górskich widoków nie oglądał, ptaki tylko latające nad nimi; dlatego dziwią i przerażają te zmiany nieustanne kolorytu, świateł, cieni i punktów widzenia. Oku tchu braknie. [...] patrzacy co chwila pragnąby szatański ten lot powstrzymać, nasycić się zmieniająca panoramą - ale nim pomyślał, już znikła. [K-1 56]

Zderzenie $z$ Zachodem jest, prócz relacji z podróży, stałym tematem rozmaitych listów Kraszewskiego. Jego publicystyka pisana od lat pięćdziesiątych stanowi, w ocenie cytowanego tu już Budrewicza, próbę zdefiniowania odmiennej rzeczywistości i zawiera przekonanie o "przejściowości" stanu duchowego Europy jako znaku czasu. W "Przeglądzie Europejskim» [Kraszewski] tłumaczył, iż cechą epoki jest jakaś "praca przygotowawcza", mająca zastapić bankructwo myśli oświecenia i chybione systemy filozofii idealistycznej"36.

Kartki z podróży są pisane przez człowieka, który, jak zauważa Budrewicz, miał do Europy Zachodniej stosunek ukształtowany przez tradycyjną niechęć do miasta oraz przez własną „szlacheckość”37. Kraszewski swoją tożsamość postrzega jako związek z rodzimą kultura i z najbliższym środowiskiem geograficznym. Dlatego obserwacje poczynione tuż po przekroczeniu granicy dotyczą odmienności zabudowy architektonicznej i przewagi krajobrazu industrialnego:

Za [...] pierwszą fabryką występuje zaraz ćma kominów i mnóstwo różnych zakładów, kraj cały sfabrykowany, nawet napisy na słupach fabrykowaną mają minę, przedestylowano je ze słowiańskich na niemieckie. [K-1 33] 
Droga z Krakowa do Wiednia oznacza dla Kraszewskiego nie tylko wkroczenie do świata odmiennego pod względem zagospodarowania przestrzeni czy przewagi budownictwa przemysłowego, ale przede wszystkim znalezienie się wśród żywiołu narodowo obcego, $w$ tym wypadku niemieckiego. Doświadczenie $z$ początku podróży powróci do pisarza niejednokrotnie - będzie on rejestrować mijane huty i fabryki (najwięcej dostrzegł ich w Belgii i te zrobiły na nim ogromne wrażenie), połączy je $\mathrm{z}$ zasobami naturalnymi oraz sposobem gospodarowania. W Belgii dokumentuje Kraszewski złoża węgla kamiennego i rud żelaza, określa liczbę oraz moc machin parowych, wymienia dziedziny przemysłu ciężkiego i lekkiego, które pracują na bogactwo (niektórych) obywateli. Oglądaną rzeczywistość, obcą, zdumiewającą rozmachem, usiłuje sprowadzić do wymiarów swego wyposażenia kulturowego. Oto jak portretuje belgijskie huty:

Dalej już dla mroku straciliśmy krajobraz z oczów i raz tylko jeszcze mieliśmy przepyszny widok nocny wielkich fabryk żelaza koło Eschweiler. Piece te, buchające płomieniami sinymi, czerwone czeluścia, krwawe dymy, szopy oświecone pomarańczowo, z ludźmi uwijającymi się po nich jak mrówki, bardzo dramatyczne piekiełko przedstawiały. Można się było sądzić w pierwszej części poematu Dantejskiego. [K-2 333]

Przekraczając kolejne granice Kraszewski również zarejestruje, bez satysfakcji, specyfikę poszczególnych kuchni narodowych ${ }^{38}$, a także - już z zainteresowaniem - oryginalność narodowych ubiorów, zabaw, sposobu bycia, odmienność urody kobiet, itd. Po drodze pisarz zaznacza cechy charakterystyczne miast - w Trieście będzie to monumentalna zabudowa $z$ „niemałą pretensją architektoniczną” (K-1 61), Werona zachwyca go willami i zamkami oraz, przede wszystkim, dziejami Romea i Julii. Bruksela widziana jest przez pisarza w perspektywie swojej najnowszej

Zob. K-1 65-66: „"Pod Czarnym Orłem“ ("Aquila Nera"), gdzieśmy stali, o godzinie obiadowej nakarmiono nas wedle obyczaju miejscowego dosyć niesmaczną strawą, która ja zniosłem z rezygnacją człowieka nie mającego apetytu, choć począwszy od białego chleba wszystko nam było wstrętliwe, ale poczciwy Klemrod - niewiele wymagający wprawdzie, koniecznie jednak tego, do czego nawykł - z germańsko-włoską kuchnią pogodzić się nie mógł i rozpaczał! Żądał zawsze barszczu i sztukamięsy, z którą się nigdzie prócz u nas zobaczyć nie można, dziwował się ludziom żyjącym słodyczami i zieleninami, a na myśl dalszych zmian, jakim żywienie się nasze ulec miało, trwożył się niepomału”. O innym posiłku, we Florencji, Kraszewski tak pisze: „Obiad, w którym, może dla Anglików, po dwakroć w różnych nieco postaciach wracał bifsztek z kartoflami, trzykroć kartofle (przez lojalność zapewne) i różne mdłe rzeczy, skończył się nareszcie z wielką dla wszystkich pociechą, bośmy wspólnie wszyscy sobie zawadzali... Francuz deser urwawszy, nim go roznosić zaczęto, wstał pierwszy i spojrzawszy na zegarek, uciekł" (K-1 207). A oto wspomnienie z Genui: „Klemrod mimo tego kataklizmu [tj. burzy] zażądał posiłku, bo lekka kawa ranna już dawno była zapomnianą, podano gęste wino czerwone, chleb szary, suchy, i kawałek sera. Wieśniacy tak samo śniadali; spróbowaliśmy więc i my, ale nie było to wyśmienite" (K-1 245). Inny obrazek, z Borghetto: „W tak zwanym "Hotelu Europejskim", który jest szumnie tylko ochrzczoną locandą, nakarmiono nas truttami, to jest pstrążkami, które się tu poławiają, i napojono bardzo brzydkim winem "della [!] cinque terre". Klemrod utrzymywał, że wolałby wino jednej jak tych "pięciu ziem" zagadkowych” (K-1 245). I jeszcze charakterystyka kuchni wiedeńskiej: „Przywykły trybem polskim do poprzedzania obiadu kieliszkiem wytrawnej starki, Klemrod wynalazł był Kirsch, o którym mówił, że był za dobry dla Niemców, chciał jeszcze koniecznie odkryć, gdzie barszcz i zrazy. Poszliśmy razem w tę podróż gastronomiczną i trafiliśmy na jakiś Braten i austriackie wino. Niemiecka kuchnia dziwną się wydawała naszym polskim żołądkom, a sławne wina mające naśladować reńskie i bordo bez patriotyzmu za codzienny napój niepraktycznymi się okazały” (K-1 48).

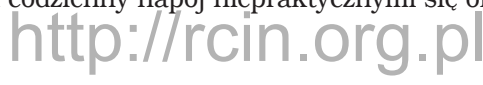


historii - przeniesienie do niej w $1831 \mathrm{r}$. instytucji stołecznych spowodowało gwałtowny i wspaniały rozwój miasta. Stała się, jak pisze podróżnik, małym Paryżem (K-2 325). Ciekawe spostrzeżenia czyni Kraszewski na temat Lipska i Drezna, które dają asumpt do wywodu o historii ziem niegdyś słowiańskich oraz prowokują do prób przewidywania kierunku rozwoju rozdrobnionych Niemiec. Pisarz na przykładzie tych dwóch miast przeciwstawia przyszłość i przeszłość, gwałtowny rozwój i trwanie tradycji, gorączkowy pośpiech i refleksję. Portret mieszkańców Lipska wyraża całą niechęć Kraszewskiego do przemian wywołanych postępem technicznym oraz ekonomicznym. Autor Kartek z podróży zauważa narodziny nowej klasy: robotników, oraz ich wrogość w stosunku do właścicieli fabryk, dokumentuje przemiany w obrębie świadomości starej arystokracji i rosnącego w siłę mieszczaństwa.

Zbliżanie się do stolicy Francji, która będzie jednym z głównych tematów opisu podróżnika, ukazane jest przez Kraszewskiego niezwykle emocjonalnie. Miasto, budzące grozę w polskich emigrantach, przytłacza wędrowca swoim ogromem i gorączkowym pośpiechem. Podróżny relacjonuje wrażenia posługując się stylem, który imituje natłok budynków i ludzi:

Nagle zaczynają się zjawiać mury, domy, ściany, ogrodzenia, bramy, kominy, całe okryte prospektami, ogłoszeniami, nazwiskami, ilustracjami, zaproszeniami. Litery sążniowe, cieniowane, złocone, czerwone, czarne pną się, cisną, kłóca, właża jedne na drugie, zdają się bić, napierając do oczu. Olbrzymi surdut na tytana skrojony zajmuje cały szczyt domu i oznajmuje mi pierwszy, że jesteśmy w Paryżu. Tak wielki surdut nie pomieściłby się w małym miasteczku. [...] W ulicach pełno wozów miejskich, zamiatacze krzątają się z miotłami, godzina szósta rano, pusto jeszcze, a już gwarno i ruchliwie. Nie ma domu bez sklepu lub sklepiku, bez drzwi, napisu i godła. Frymark panuje tu... Handel! Handel! [K-2 256]

Paryż, w XIX w. miejsce życia setek polskich emigrantów, nie cieszył się wśród nich dobrą opinią. Porównywany z pozostawionymi w kraju miejscami rodzinnymi, wydawał się całkowicie obcy, zwłaszcza że pobyt w nim był ze względów politycznych bardzo często przymusowy. Łaczył się ponadto $z$ utratą regularnych dochodów ziemskich i zdaniem się na cudzą łaskę lub na pracę własnych rąk (taki obraz, co prawda w realiach niemieckich, maluje np. powieść Kraszewskiego Na tułactwie). Przebywanie w Paryżu wiązało się z poczuciem uprzedmiotowienia człowieka, a także z jego anonimowością. Dla autora Kartek z podróży stolica Francji stała się synonimem nieuniknionego i odhumanizowanego postępu w Europie oraz miara rozwoju wszystkich oglądanych miast Zachodu. Przyjeżdżający do Paryża pisarz miał z pewnościa za sobą lekture Epilogu z Pana Tadeusza i wierszy Słowackiego, musiał znać historię polskiej emigracji. W swoich Kartkach z podróży zdał relację z wizyty w mieszkaniu Norwida. Ocena dorobku poety, dokonywana razem z refleksją na temat twórczości wieszczów, wyrosła z przekonania Kraszewskiego o historycznym już znaczeniu wielkich emigrantów. Ich postawa i problemy, którymi żyli, wydawały mu się anachroniczne. Wprawdzie okres, gdy nastapiło spotkanie z Paryżem - koniec lat pięćdziesiątych XIX w. - nie mógł go uprawnić do spoglądania na dzieło największych polskich poetów jako na zamierzchłą i zamkniętą przeszłość, jednak Kartki $z$ podróży pisane są z dystansem do epoki romantyzmu, z pozycji trzeźwego obserwatora rozwijającej się Europy. O wieszczach wypowiada się Kraszewski tak: „Egzaltacja, jaką wypadki wyrobiły, Mickiewicz, Krasiński, Słowacki, naturalne owoce tej epoki, stworzyły też takich nieszczęśliwych Cypria-

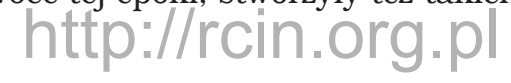


nów [...]" (K-2 318). Usytuowanie emigracyjnych poetów na tle minionej epoki było efektem wyraźnego już oddalenia artystycznego i egzystencjalnego podróżnika, wiązało się zapewne także $z$ jego doświadczeniami $z$ dotychczasowego wojażu po Europie. Pisarz, podziwiający zabytki kultury, zwracał przecież uwagę na dokonujący się postęp, nawet jeśli jego przejawy konstatował z niechęcią.

Rozwój handlu, stanowiący źródło bogactwa mieszczan paryskich, odbierany był przez Kraszewskiego jako dążenie do życia pozbawionego refleksji, zaspokajającego jedynie materialne potrzeby. $\mathrm{W}$ takim duchu pisarz przeciwstawiał stolicę Francji, „pandemonium cywilizacji” (K-2 306), miastom włoskim:

Z końca w koniec przebiegając miasto widziałem tylko ludzi, co sprzedawali, i ludzi, co łaknęli zabawy, rozrywki, popisu. W tłumie ich nikły i ginęly wyjątkowe postacie ożywione innym celem i myślami. Pamiątki cesarstwa, Orleanów, Burbonów, rewolucji, różnych epok, dynastii spotyka się po mieście jak archeologiczne zabytki ciekawe, a nie obchodzące nikogo. Francuzi biegną na bursę i nie entuzjazmują się niczym. To zaprzątnienie zyskiem, handlem, zbogaceniem dla używania na pierwszy rzut oka było bardzo uderzającym.

W miastach włoskich przez ruiny i łachmany patrzy myśl jakaś, żal, boleść, miłość - tu wszystkimi szpary wygląda złoto. [K-2 266]

Zestawiając Paryż z miastami włoskimi Kraszewski podkreślał uleganie presji chorobliwego postępu, brak pamięci o przeszłości, materializm i egoizm mieszkańców stolicy Francji - w odróżnieniu od melancholii i uczuciowości widocznej wśród Włochów. W porównaniu z miastami niemieckimi metropolia nad Sekwaną uderzała podróżnika swoją troską o pozór, zewnętrzny polor, charakterystycznym dla rozwoju cywilizacyjnego skupieniem na powłoce życia. Ukrywała ona najczęściej „zaniedbanie i nieuctwo” (K-2 320), a także brak zdrowych podstaw moralnych w społeczeństwie. Kraszewski, obserwator cywilizacji zachodniej, pod powierzchnia egzystencji łatwiejszej, wygodniejszej i bardziej uporządkowanej niż na wschodzie Europy znajduje rysy, szpary, pęknięcia i znamiona przyszłej ruiny. Dostrzega też hipokryzję, która przejawia się choćby w stosunku do śladów przeszłości. Już we Florencji raziło pisarza umieszczenie na ołtarzach w katedrze „dzisiejs zych posągów z papier-mâc hé, najobrzydliwszej trywialności” (K-1 318). Podczas pobytu w Paryżu Kraszewski pisze:

Cywilizacja dzisiejsza, przy całym swym poszanowaniu wrzekomym przeszłości, jest okrutna: kolej żelazna nie przebacza pomnikom, handel śmieje się z pamiątek, przemysł rozpiera się w najstarszych murach bez zgryzot sumienia.

$[\ldots]$

Ludzie praktyczni mogą mieć nam za złe, że się powodujemy tak błahymi dla nich uwagami, ale któż obrachował kiedy, czy widok ruin i grobów nie jest dla ludzkości koniecznym i potrzebnym, czy zniszczywszy je, nie odjęłoby się człowiekowi zbawiennego pokarmu ducha? Dziś on potrzebny, a choćby najprodukcyjniejsze warzywo wyrosło na miejscu kośćmi użyźnionym, któż wie, czy i koście nie produkcją? Z kości się rodzą mściciele nie ludzi, ale idei sponiewieranych i prawd pogrzebionych. [K-1 403-404]

Odwołanie się do Eneidy służy Kraszewskiemu jako uzasadnienie poglądów estetycznych, w istocie zawierających wykład historiozofii. Trudno odmówić pisarzowi przenikliwości, która wydaje się tyleż efektem zmysłu obserwacyjnego, co konsekwencją doświadczeń historycznych, wpływających na ukształtowanie tożsamości podróżnika. Wcześniej, zanim Kraszewski wyjechał zwiedzać kolebkę cy-

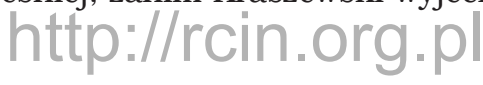


wilizacji, odbywał podróże po ziemiach polskich, tropiąc i utrwalając ślady minionej wielkości Rzeczpospolitej. Zwiedzał zabytki Wołynia, Litwy, Polesia ze świadomościa, że epoka ich świetności przeminęła. Odbywana „w naturze” lekcja historii musiała zdeterminować zdolności postrzegania podróżnika. Pamięć o pochodzeniu, nieusuwalne wyposażenie kulturowe w jedyny możliwy sposób podyktowały Kraszewskiemu zasady oglądu Europy Zachodniej. Mimo że o zawartości muzeów i o zabytkach architektury wypowiada sie jak znawca, Kraszewski pozostaje wobec Francji czy Włoch obcy. Jego spojrzenie zawsze jest z zewnątrz, spoza granic tego świata. Mijane budowle i krajobrazy są przedmiotem zachwytu, ale też trzeźwej oceny „nosiciela historii".

$\mathrm{W}$ wieku XX powtórzy gest konfrontacji nierównych światów $\mathrm{z}$ dwóch stron żelaznej kurtyny „barbarzyńca w ogrodzie”, Zbigniew Herbert, jako autor cyklów esejów powstałych z podróży po Włoszech, Grecji, Francji i Niderlandach. Obaj pisarze: XIX-wieczny podróżnik i jego następca, sa przekonani, że „estetyka może być pomocna w życiu”, jak głosi wiersz Herberta Potęga smaku ${ }^{39}$, a - przy wszystkich odmiennościach $\mathrm{w}$ ich formacji intelektualnej - potęga smaku pozwala nie tylko odróżnić piękno od brzydoty, ale także przenieść te kategorie na płaszczyznę moralna. Oglądanie historycznych budowli, rzeźb i obrazów zamienia się pod piórem obu twórców w hermeneutykę dziejów poszczególnych narodów, dąży do odgadnięcia celu i sensu etapów ich aktywności, rozwoju i zmierzchu. Obaj prezentuja pogląd, że postęp bez wyraźnego nakreślenia efektów, bez odwołania się do wyższych wartości, odbywany dla samego ruchu, zmiany, jest tylko fetyszem nowoczesności. Herbert przenosi jego kategorie na historię sztuki: „Jeśli oceniać dzieło według tego, jak "popycha" ono sztukę naprzód, to obraz Sassetty jest skandalicznie anachroniczny i dowodzi ślepoty artysty na to, co "nowe» [...]. A mimo to trudno oderwać się od Sassetty" ${ }^{40}$. Kraszewski pisze na marginesie oglądanego hasła austriackiego towarzystwa ubezpieczeniowego, na samym początku swojej podróży: „Tak jest, naprzód! Naprzód! Ale dokąd? Ale po co? Czy to "naprzód" wyznacza drogę całej ludzkości, czy tylko monarchii, co by jak najwięcej pochłonąć chciała [...]?” (K-1 60). Odczytane na początku drogi po Europie hasło kieruje uwage pisarza w stronę interesów ukrywających się za zasłoną postępu. Rozwój pojmowany jako realizacja imperialnych pretensji jest dla Kraszewskiego znakiem wyradzania się cywilizacji, niezdrowych ambicji w duchu nieumiarkowanego konsumpcjonizmu. Pochłanianie przez przedsiębiorstwa czy państwa coraz to nowych terytoriów okazuje się taką miara postępu, który - jak przekonuje lekcja historii odbywana przez pisarza podczas podróży - prowadzi jedynie do upadku i unicestwienia podmiotu. Podobne przeświadczenie prezentuje Herbert na marginesie swoich refleksji o minionych potegach państwowych czy religijnych.

Obaj twórcy, choć wyposażeni w fachową wiedzę na temat oglądanych miast i zabytków, cenią sobie przechadzki bez planu. Kraszewski tak opisuje swoje spotkanie z Genuą: „Nie biorąc wcale przewodnika i błądząc na los szczęścia po mieście, odbyłem po nim pierwszą wielce nauczająca przechadzkę" (K-1 229). Podczas podróży wielokrotnie pozwala sobie na wędrówki bez ustalonego programu, „dla za- 
bicia czasu” (K-2 348), jak we Frankfurcie, gdzie nastąpiła nieprzewidziana przerwa, spowodowana brakiem pociągu o określonej godzinie. Herbert wędrówkom bez planu poświęca sporo miejsca, tworzy niemal apologię takiego sposobu zwiedzania obcych miast: „Zeszyt i szkicownik idą do kieszeni i zaczyna się najprzyjemniejsza część programu - flanowanie, to znaczy: włóczenie się bez planu według perspektyw, a nie przewodników [...]"41. Prezentowana przez obu podróżników postawa wynika z poczucia podmiotowej wolności, która pozwala przeciwstawić się dyktatowi metodyki podróżowania - z przeznaczonymi do zwiedzania obiektami i maksymalnym zagospodarowaniem czasu poświęcanego na poszczególne zabytki. Ukazuje radość takiego marnotrawstwa i otwarcie się na wrażenia niespodziewane, nie przewidziane w planie podróży. Nie ma to wiele wspólnego $z$ wyróżnionymi przez Zygmunta Baumana typami osobowości ponowoczesnej. Pisarze nie są „turystami” czy „włóczęgami”, mają bowiem określoną tożsamość, wynikającą z zakorzenienia w czasie i miejscu.

Dzięki spojrzeniu na zwiedzaną Europe poprzez historię nie występuje w postawie podróżników poczucie niższości cywilizacyjnej, świadomość przynależności do gorszego miejsca na kontynencie. Zarówno Kraszewski, jak Herbert akcentuja swój udział w cywilizacji europejskiej i jednocześnie głęboki związek z własną kultura oraz z pozornie nieatrakcyjnymi krajobrazami ziem rodzimych. Obaj, w ślad za Mickiewiczowskim wzorem konfrontacji włoskiego błękitu nieba $z$ polskimi chmurami, cierpią na to, co zostało w Panu Tadeuszu określone słowami: „Sopliców choroba, / Że im oprócz Ojczyzny nic się nie podoba"42. Kraszewski w swoich Gawędach o literaturze i sztuce nawołuje do oglądania krajobrazów wołyńskich czy poleskich przez pryzmat przywiazania do ojczyzny. Estetyka jest w jego postulatach funkcją emocji. Pisze on:

Szukajmy tylko natchnienia, a znajdziemy, pracujmy, a stworzym piękność naszą, ale artyście wybierającemu się w wędrówkę malowniczą po kraju, nie teki tylko, ołówka i dobrej woli; więcej, więcej czegoś potrzeba!

[...] trzeba koniecznie kochać ją [tj. naturę], by pojacć, wcielić się w nią, zjednoczyć, wdumać, i czekać, aż zstąi i opromieni natchnienie ${ }^{43}$.

Jeszcze wyraźniej soplicowski gust ujawnia się, gdy pisarz wprost przyrównuje krajobrazy włoskie do rodzimych. W okolicach Pizy uderza go podobieństwo oglądanej przyrody do „naszego litewskiego, jakbyś go widział, borku sosnowego na piasku” (K-1 251) ${ }^{44}$.

Herbert w swojej poezji deklaruje niejednokrotnie ścisły związek z określonym w „gorszej” części Europy miejscem życia, w sąsiedztwie „rowu, w którym płynie

A. Mickiewicz, Pan Tadeusz, czyli Ostatni zajazd na Litwie. Historia szlachecka z roku 1811 i 1812 we dwunastu księgach wierszem. Oprac. S. Pigoń. Wyd. 8. Wrocław 1980, s. 187. BN I 83.

Jednak dodaje dalej pisarz, że podobieństwo sosen było złudne: „Chociaż rozczuliliśmy się lasem sosnowym na piasku, wjechawszy weń, prawda przyznać każe, iż po bliższym wpatrywaniu się, sosny te wielce się od naszych różniły. Rosły tylko na szczerym i białym piasku jakby nasze" (K-1 252).

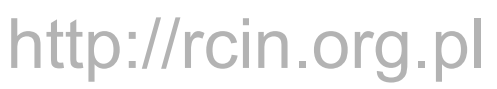


mętna rzeka" ${ }^{25}$. Dylematy emigracyjne rozwiąuje jednoznacznie, czego przykładem jest choćby wiersz Widokówka od Adama Zagajewskiego albo utwór wcześniejszy, pochodzacy z tomu Studium przedmiotu (1961), zatytułowany Powrót prokonsula, w którym persona liryczna uosabia przekonania XX-wiecznego poety:

postanowiłem wrócić jutro lub pojutrze

nie mogę żyć wśród winnic wszystko tu nie moje

drzewa są bez korzeni domy bez fundamentów deszcz szklany kwiaty pachną woskiem

o puste niebo kołacze suchy obłok ${ }^{46}$

Zarówno w XIX, jak i w XX w. perspektywą, z jakiej ocenia się świat Europy Zachodniej, jest, zaznaczane już, poczucie historycznej i kulturowej odmienności podróżników. Kraszewski i Herbert, „prowincjusze Europy”, podobnie jak dawniej oświeceniowi krytycy idei postępu, odrzucają pochwałę progresywizmu opartą na pozorach, szukając trwałych fundamentów etycznych upostaciowanych w przejawach współczesnego sobie życia gospodarczego oraz w budowlach i pomnikach dziejów narodów. Interesuje ich postęp oparty na najlepszej śródziemnomorskiej tradycji, ale odbywający się z poszanowaniem dla poszczególnych, narodowych realizacji. Przykład Wenecji we wspomnieniach Kraszewskiego z podróży to najlepszy dowód brzemiennego w skutkach złudzenia, że rozwój nie wymaga ciagłej pracy w duchu pieleggnowania tradycyjnych wartości. XIX-wieczny pisarz uwrażliwiony jest dodatkowo na dokonującą się w Europie Zachodniej laicyzację, która niepokoi przez to, że otwiera miejsce na przyjęcie nowych, nieznanych idei.

W swoim rozumieniu „niepohamowanego”, jak określa go autor Kartek z podróży (K-1 78), postępu cywilizacyjnego obaj pisarze rezygnują $z$ bezrefleksyjnych wrażeń, nie pogłębionych o wiedzę i nie przefiltrowanych przez własny wzór kulturowy. Kraszewski tak rozpoczyna swoją relację z podróży po Europie: „Nieznane! Nowe! Słowa wielkiego uroku dla każdego, choć z Emersonem przychodzi na myśl ta prawda, że wszędzie znajdujemy siebie i to, cośmy z rodzinnego kątka wywieźli” (K-1 9). Herbert, wbrew chłodnemu obiektywizmowi i dystansowi, z jakim przypomina o romantycznym rodowodzie podróży, reprodukuje XIX-wieczny wzór poznania, tyleż otwarty na nowe doświadczenia, co nastawiony na własną podmiotowość.

Podobnie jak w XX w. Herbert, tak też Kraszewski jest świadomy, że obcowanie $\mathrm{z}$ każdą sztuką, w tym również europejską, wymaga cierpliwości i skupienia:

Jak pobieżne czytanie, tak i oglądanie płoche nic nie uczy, zaspokaja próżność, nie bogaci umysłu. $Z$ mistrzem i dziełem należy się zapoznawać powoli, wnikać weń, usiłować go zrozumieć, pracować nad rozdarciem zasłon, nad wyszukaniem piękności. [K-1 309]

Zapisane dzieje i teraźniejszy do nich stosunek lepiej definiują kierunek postępu cywilizacyjnego niż najbardziej wyraziste deklaracje ideowe. Podejrzliwość wobec słów jest cechą wspólną obu pisarzy.

Refleksyjny stosunek do wynalazków technicznych oraz spowodowanych przez nie zmian politycznych i społecznych wprowadza w obręb zainteresowania podróżników los narodów zwyciężonych, które przegrały wyścig z czasem i z rozwojem

Z. He rb e rt, Prolog. W: Wiersze zebrane. Oprac. edytorskie R. Kry n i cki. Kraków 2008, s. 317.

Z. He rb ert, Powrót prokonsula. W: jw., s. 269.

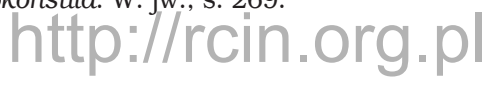


wymiany towarowej czy środków zabijania. Zarówno Kraszewski, jak Herbert w swoich książkach poświęcają miejsce Etruskom, jako zdolniejszym poprzednikom Rzymian, pokonanym przez nich na drodze przemian cywilizacyjnych. Kraszewski zaznacza w swoich Kartkach z podróży: „To, czego Rzymianom w sztuce brakło, oryginalności, miała [sztuka] etruska, choć do wysokiego stopnia doskonałości nie doszedłszy - pochłoniętą została” (K-1 490). Herbert poświęca Etruskom cały esej w cyklu Labirynt nad morzem. Zaginiona w mrokach historii cywilizacja, jej sztuka oraz dzieje jej narodzin i upadku wydają się szczególnie istotne dla XX-wiecznego podróżnika. Ukazują bowiem ten wymiar historii, z którym - chcąc nie chcąc - może się on zidentyfikować. Pisze Herbert:

Być może, iż obraz losu Etrusków jest rezultatem tego, że widzimy ich wyłącznie w świetle obcych źródeł. Są więc jakby przedmiotem historii, a nie świadomym podmiotem, który usprawiedliwia się, tłumaczy swoje klęski, dopomina się o łagodny wyrok potomnych, o łaskę wyrozumiałości ${ }^{47}$.

Przedstawiciel „gorszej” części Europy znajduje w dziejach Etrusków potwierdzenie własnej kondycji. Styczność z pozostałościami po artystycznych dokonaniach mieszkańców Etrurii to coś więcej niż tylko wyprawa w głąb historii sztuki i wędrówka po obcych geograficznie krajach. Pisze Herbert, że sztuka ta „staje się znakiem i świadectwem utrwalonej obecności" ${ }^{48}$, i rejestruje proces uwalniania swoich władz poznawczych od utartych przekonań i stereotypów. Kontakt z dziedzictwem Etrusków okazuje się prawdziwym zdarzeniem, autentycznym spotkaniem osób, z których każda jest zanurzona we własnej dziejowości. Józef Ignacy Kraszewski, XIX-wieczny podróżnik, konfrontuje oglądany przez siebie obcy świat z doświadczeniem rozgrywajacej się teraz, współcześnie, historii. I dla niego ważniejsze staje się bezpośrednie obcowanie $z$ noszącym znamiona przeszłości pięknem niż napierające zewsząd znaki rozwoju cywilizacji, symptomy dokonujących się zmian na kontynencie europejskim. Otoczony hałaśliwymi miastami, autor Kartek $z$ podróży odnajduje spokój w muzeach i świątyniach. Obcowanie ze sztuką jest dla niego czymś więcej niż tylko ucieczką od handlu, przemysłu oraz alienacji, rozwijających się w wieku wzmożonego postępu technicznego i ekonomicznego. Wspomnienia $z$ wędrówek po „innym świecie” utwierdzają Kraszewskiego w jego tożsamości i wskazują na wartości niezależne od upływu czasu.

Abstract

AGNIESZKA CZAJKOWSKA Jan Długosz University, Częstochowa

JÓZEF IGNACY KRASZEWSKI TOWARDS EUROPEAN CIVILISATION PROGRESS ON THE MARGIN OF TRAVEL ACCOUNT

Kraszewski's understanding of progress is composed of many elements: knowledge of natural sciences, technical inventions awareness, supported by professional archive research in history and the processes that control it, observation of economical, industrial and social changes in Poland and in Europe, as well as perfect education in art history and the ability of defining the development of particular

Z. H e r b e r t, O Etruskach. W: Labirynt nad morzem. Warszawa 2000, s. 151.

Ibidem, s. 161 .

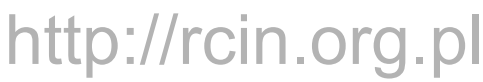


aesthetic styles. Kraszewski's attitude to the quickly developing European civilisation evolved. He used the categories of progress to observe the social situation of Volhynia, where he lived, the arising in Warsaw consumerist lifestyle and the Western Europe economical development, the expressions of which are his memories entitled Kartki $z$ podróży (Notes from Travels). In the collection Kraszewski highlights lifestyle unification and decline of national values. Under the cover of easier, more comfortable and more ordered than in the East existence, he finds scratches, cracks, bursts, and traits of future ruin. The novelist, as earlier the Enlightened critics of the idea of progress did, rejects the praise of progressivism based on appearances, and looks for solid ethical fundaments in the real manifestations of contemporary to him economical life, as well as in buildings and in monuments of national history. He is interested in the progress based on the best Mediterranean tradition which also respects individual and national realisations. 